ARTICLE

https://doi.org/10.1038/s41467-020-14490-y

\title{
Initiation of a stable convective hydroclimatic regime in Central America circa 9000 years BP
}

\author{
Amos Winter ${ }^{1,2 \star}$, Davide Zanchettin ${ }^{3}$, Matthew Lachniet (10 4, Rolf Vieten ${ }^{2,5}$, Francesco S.R. Pausata ${ }^{6}$, \\ Fredrik Charpentier Ljungqvist (10 7,8, Hai Cheng9 ${ }^{9} 10$, R. Lawrence Edwards ${ }^{9}$, Thomas Miller ${ }^{11}$, Sara Rubinetti ${ }^{12,13}$, \\ Angelo Rubino ${ }^{3} \&$ Carla Taricco $^{12,13}$
}

\begin{abstract}
Many Holocene hydroclimate records show rainfall changes that vary with local orbital insolation. However, some tropical regions display rainfall evolution that differs from gradual precessional pacing, suggesting that direct rainfall forcing effects were predominantly driven by sea-surface temperature thresholds or inter-ocean temperature gradients. Here we present a 12,000 yr continuous U/Th-dated precipitation record from a Guatemalan speleothem showing that Central American rainfall increased within a $2000 \mathrm{yr}$ period from a persistently dry state to an active convective regime at $9000 \mathrm{yr}$ BP and has remained strong thereafter. Our data suggest that the Holocene evolution of Central American rainfall was driven by exceeding a temperature threshold in the nearby tropical oceans. The sensitivity of this region to slow changes in radiative forcing is thus strongly mediated by internal dynamics acting on much faster time scales.
\end{abstract}

\footnotetext{
${ }^{1}$ Department of Earth and Environmental Systems, Indiana State University, Terre Haute 47809 IN, USA. ${ }^{2}$ Department of Marine Sciences, University of Puerto Rico, Mayaguez 00680 Puerto Rico, USA. ${ }^{3}$ University Ca' Foscari of Venice, Department of Environmental Sciences, Informatics and Statistics, Via Torino 155, 30172 Mestre, Italy. ${ }^{4}$ Department of Geoscience, University of Nevada Las Vegas, Las Vegas 89154 NV, USA. ${ }^{5}$ Institute of Earth Sciences, Hebrew University of Jerusalem, Jerusalem, Israel. ${ }^{6}$ Centres ESCER (Étude et la Simulation du Climat à l'Échelle RÉgionale) and GEOTOP (Research Center on the dynamics of the Earth System), Department of Earth and Atmospheric Sciences, University of Quebec in Montreal, Montreal, QC, Canada.

${ }^{7}$ Department of History, Stockholm University, SE-106 91 Stockholm, Sweden. ${ }^{8}$ Bolin Centre for Climate Research, Stockholm University, SE-106 91 Stockholm, Sweden. ${ }^{9}$ Department of Earth Sciences, University of Minnesota, Minneapolis, MN 55455, USA. ${ }^{10}$ School of Human Settlement and Civil Engineering, Xi'an Jiaotong University, Xi'an 710049, China. ${ }^{11}$ Department of Geology, University of Puerto Rico, Mayaguez 00680 Puerto Rico, USA. 12 Physics Department, University of Torino, via Pietro Giuria 1, 10125 Torino, Italy. ${ }^{13}$ Istituto Nazionale di Astrofsica, Osservatorio Astrofisico di Torino (OATo-INAF), Strada Osservatorio 20, 10025 Pino Torinese, Italy. *email: amos.winter@indstate.edu
} 
n orbital time scales, many paleoclimate records in tropical regions are linked to gradual variations in incoming solar radiation ${ }^{1}$ associated with changes in the Earth's orbital parameters. For example, the Earth's precession variability produces insolation anomalies on time scales of $\sim 19,000$ and $\sim 23,000$ years that have led to slow variations in regional climate and hydroclimate over the subtropical latitudes of SouthEast and East Asia, as well as South and North America, as shown by a tight correlation between summer insolation and proxies of integrated precipitation strength ${ }^{2-7}$. In southern Central America, the convergence of moisture related to the Intertropical Convergence Zone (ITCZ) produces heavy convective rainfall over land ${ }^{2}$ with an annual peak between June and October. However, some near-equatorial paleoclimatic records feature characteristics inconsistent with summer insolation changes, e.g., in Australia ${ }^{3}$, on the Pacific coast of Costa Rica in Central America ${ }^{4}$, and in Borneo on the Western Tropical Pacific ${ }^{5}$. Some other records suggest relatively stable Holocene rainfall despite changing insolation, e.g., the Liang Luar Cave record from Indonesia ${ }^{6}$ and the sediment record from Lake Petén Itzá in Guatemala ${ }^{7}$. The contrast between records showing orbital variability and records apparently unaffected by such variability highlights the considerable spatio-temporal complexity of tropical hydroclimates around the globe and their different sensitivity to external forcings.

In Central America the marked heterogeneity of modern hydroclimate regimes arises from interacting atmospheric, oceanic, and land processes that occur in this narrow stretch of land separating the tropical Pacific and tropical North Atlantic oceanic basins ${ }^{8-12}$. The same processes explain the strong sensitivity of this region to external forcing. Stalagmite records suggest that externally forced multidecadal anomalies in Atlantic and Pacific sea-surface temperatures (SSTs) significantly made an imprint on Central American rainfall evolution throughout the past few centuries $^{8}$. Model projections ${ }^{13}$ under global warming scenarios suggest that a similar chain of mechanisms may be responsible for a potential substantial drying of more than $30 \%$ over Central America. However, whether such strong sensitivity to warming and associated dynamics is a persistent characteristic of local climate is uncertain due to the few continuous multi-millennial and accurately dated paleoclimate archives for this region ${ }^{14,15}$. Together with knowledge gaps about general long-term hydroclimate variability ${ }^{16,17}$ and difficulties of current climate models to robustly simulate large-scale oceanic and atmospheric phenomena linked to Central American rainfall ${ }^{18-20}$, this uncertainty simply corresponds to a poor understanding of the prime controlling mechanisms of Central American hydroclimate.

Available paleoclimate reconstructions from Mesoamerica do not provide a consistent description of the Central American hydroclimatic state and variability during the Holocene. A speleothem rainfall reconstruction spanning the last 100,000 years from Barra Honda National Park, Costa Rica $\left(10^{\circ} \mathrm{N}\right.$; Supplementary Fig. 1) is poorly explained by the orbital paradigm, and it appears instead to be largely controlled by Caribbean-Pacific SST gradients ${ }^{4}$. However, this speleothem record does not capture the end of the last deglaciation and the whole Holocene. In contrast, Mexican speleothems from the Mesoamerican region $\left(18^{\circ} \mathrm{N}\right.$; Supplementary Fig. 1) indicate that the local, long-term rainfall evolution during the Holocene was paced by insolation changes? However, the Mexico records also exhibit pronounced millennialscale variability possibly reflecting a contribution by internal processes, specifically from North Atlantic SSTs and variations in the oceanic thermohaline circulation. Such dynamical interpretations must also account for the possible inconsistencies between hydroclimate reconstructions obtained for the same region from different paleoclimate archives ${ }^{21}$.
In this study, we present a new Holocene rainfall-sensitive speleothem record (GU-RM1, Fig. 1, Supplementary Fig. 1; see Methods section for more details) from Rey Marcos cave located at $1460 \mathrm{~m}$ altitude $\left(15.4^{\circ} \mathrm{N}, 90.3^{\circ} \mathrm{W}\right)$ on the Caribbean slope of Central America in the Guatemalan highlands. This is currently the first and best-dated published high-resolution speleothem record from Central America that continuously spans the Holocene. The data show that variability of Central American rainfall evolved through three major phases: a relatively sharp wetting in the early Holocene (11,000-9000 years before the present (yr $\mathrm{BP})$ ), a stable regime from 9000 to $5000 \mathrm{yr} \mathrm{BP}$, a centennial scale drying period between 5000 and $4000 \mathrm{yr}$ BP, and a subsequent tendential drying that persists to the present. Supported by climate model simulations, the transition from a dry into a persistently active convective regime around $9000 \mathrm{yr}$ BP was largely enhanced by tropical Atlantic SST warming, while being relatively insensitive to local insolation variations. Our record represents a significant advance on previous studies because of the highprecision U-series dating of the rainfall strengthening that is unaffected by issues associated with radiocarbon calibration and problems related to carbon cycling in lake sediments.

\section{Results and discussion}

Wettening in the early Holocene followed by stable conditions. The calcite GU-RM1 speleothem has a robust age model (Fig. 1b)
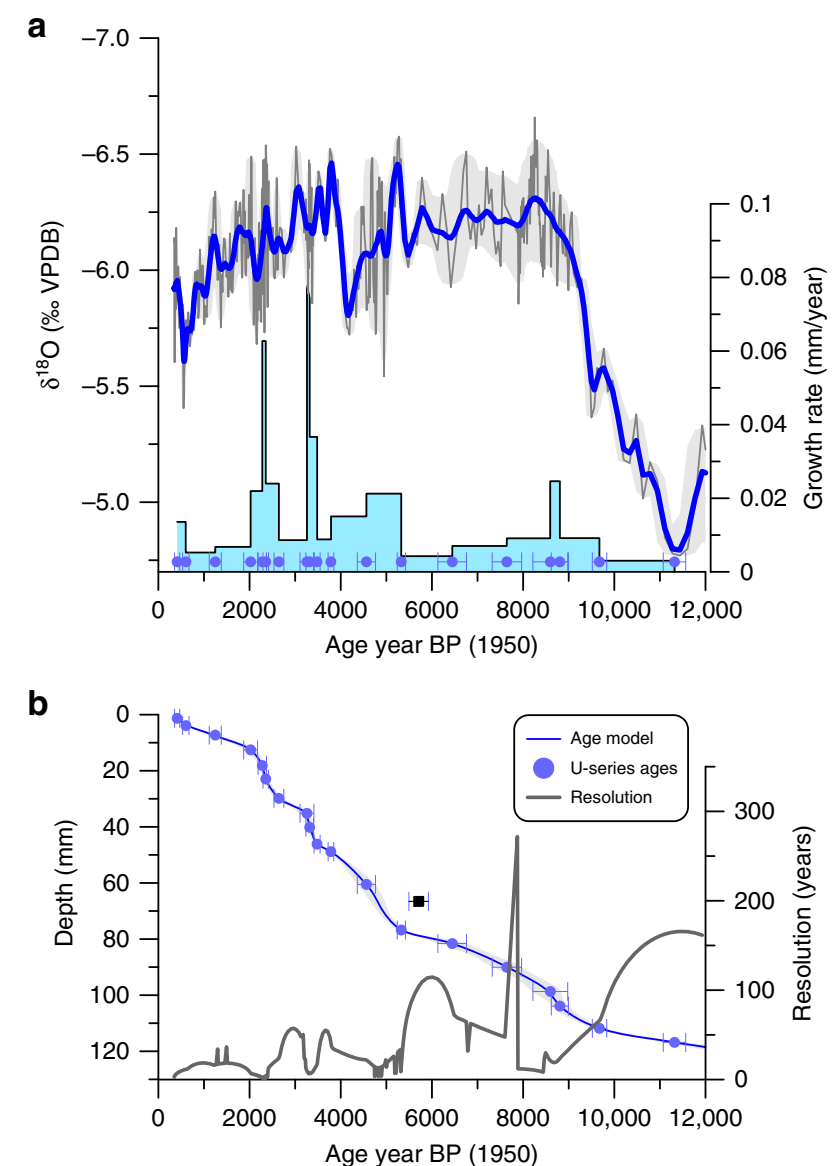

Fig. 1 Central American rainfall time series inferred by GU-RM1. a GU$\mathrm{RM} 1 \delta^{18} \mathrm{O}$ time series (gray line and gray shading: measured values and age uncertainties; bold blue line: COPRA ${ }^{61}$ output time series). b Age-depth model for ${ }^{230}$ Th dates with gray uncertainty envelope from the COPRA modeling. The date at $67 \mathrm{~mm}$ depth was omitted from the age model and is shown for reference as a black square. The gray line shows the $\delta^{18} \mathrm{O}$ sampling resolution (years between samples). 
constrained by twenty-one U/Th multi-collector inductively coupled plasma mass spectrometry dates (Supplementary Table 1, Supplementary Fig. 1), which show slow but apparently continuous growth from $\sim 12,700 \mathrm{yr} B P$ (below the lowest date at $11,320 \pm 247 \mathrm{yr} \mathrm{BP}$ ) to $\sim 300 \mathrm{yr}$ BP (see Supplementary Information). This slow growth preserves a uniquely long Holocene climate history for this humid tropical region. Because the amount effect is the dominant control on $\delta^{18} \mathrm{O}$ variations in Central America $^{22}$ and the Yucatán lowlands ${ }^{23}$, and the Caribbean slope is dominated by a single oceanic moisture source (the Caribbean Sea), we interpret the $\delta^{18} \mathrm{O}$ variations in the stalagmite as reflecting regional convective intensity. The most prominent aspects of our record are a sharp decrease of $1.3 \%$ in $\delta^{18} \mathrm{O}$ values in the early Holocene (between 11,000 and $9000 \mathrm{yr}$ BP), linked to increased rainfall over Central America, and the following period of relatively stable conditions during the last $9000 \mathrm{yr} \mathrm{BP}$, when $\delta^{18} \mathrm{O}$ values range between -6.6 and $-5.5 \%$ VPDB (Fig. 1a). Our reconstruction contains a significant but small drying trend of $0.0325 \pm 0.0037 \% / 1000 \mathrm{yr}$ over the last $9000 \mathrm{yr}$ BP. The last 3.5 millennia exhibit a trend from -6.5 to $-5.5 \%$ VPDB indicative of reduced precipitation as commonly reported for other records $1,9,10,15$

The main characteristics of the Guatemalan rainfall record from GU-RM1 agree with the characteristics found in the Petén Itzá lacustrine sediment $\delta^{18} \mathrm{O}$ record ${ }^{24}$, which describes changes in the balance between precipitation and evaporation in the Guatemalan lowlands (Fig. 2a, d) and in the Lake Quexil pollen record ${ }^{25}$. Specifically, all records depict the dry-to-wet transition between 11,000 and $9000 \mathrm{yr}$ BP with the relatively stable hydroclimate conditions thereafter, and a drying trend is established during the last two millennia. The agreement between the GU-RM1 record of precipitation intensity and the Petén Itzá $\delta^{18} \mathrm{O}$ record of precipitation minus evaporation suggests that increased rainfall amount is also related to a decrease in evaporation as evident in lower $\delta^{18} \mathrm{O}$ values in the lake record. Because the GU-RM1 record is precisely dated and is less influenced by evaporative increases in $\delta^{18} \mathrm{O}$ like Lake Petén Itzá, it is a more direct proxy of variations in the $\delta^{18} \mathrm{O}$ of precipitation. The beginning of the dry-to-wet transition has a similar onset in both the Cariaco Basin 26,27 (Fig. 2g) at $\sim 11,600 \mathrm{yr}$ BP and GURM1 at $\sim 11,400 \mathrm{yr}$ BP, well within the age uncertainty of our age model at this time ( \pm 260 years). While the transition to early Holocene wetness in the Cariaco record was mostly complete by $\sim 10,300 \mathrm{yr}$ BP and coincident with the peak in July 21 insolation, the transition in Guatemala did not reach completion until $\sim 9000 \mathrm{yr}$ BP. Rainfall then decreases abruptly at $\sim 4000 \mathrm{yr}$ BP in northern South America, while Guatemala rainfall decreased gradually in the Late Holocene starting 3800 to $400 \mathrm{yr}$ BP. These contrasting observations reveal a latitudinal differentiation of ITCZ-related rainfall.

Interestingly, the GU-RM1 $\delta^{18} \mathrm{O}$ record is not correlated with July 21 insolation during the last 12,000 yr BP $(r(p)=-0.049$ (0.925), see also Fig. 2a, b). Indeed, the shape of the GU-RM1 curve does not exhibit a sine-wave like evolution over the course of the Holocene, as would be predicted if orbital insolation in any month was the dominant control on Central American rainfall. This contrasts with other nearby rainfall hydroclimate records, including the Cariaco Basin which closely follows July 21 insolation, at essentially the same latitude of $15^{\circ} \mathrm{N}$. The correspondence of boreal summer insolation and the latitudinal migration of the ITCZ has underpinned the dominant paradigm of climatic variation on Holocene time scales for the neo-tropics, yet it fails to explain the full Holocene evolution of rainfall in Guatemala. Further, local summer insolation has been used to interpret the Huagapo speleothem $\delta^{18} \mathrm{O}$ record ${ }^{28}$ (not shown) from South America, and the Juxtlahuaca and Diablo Caves

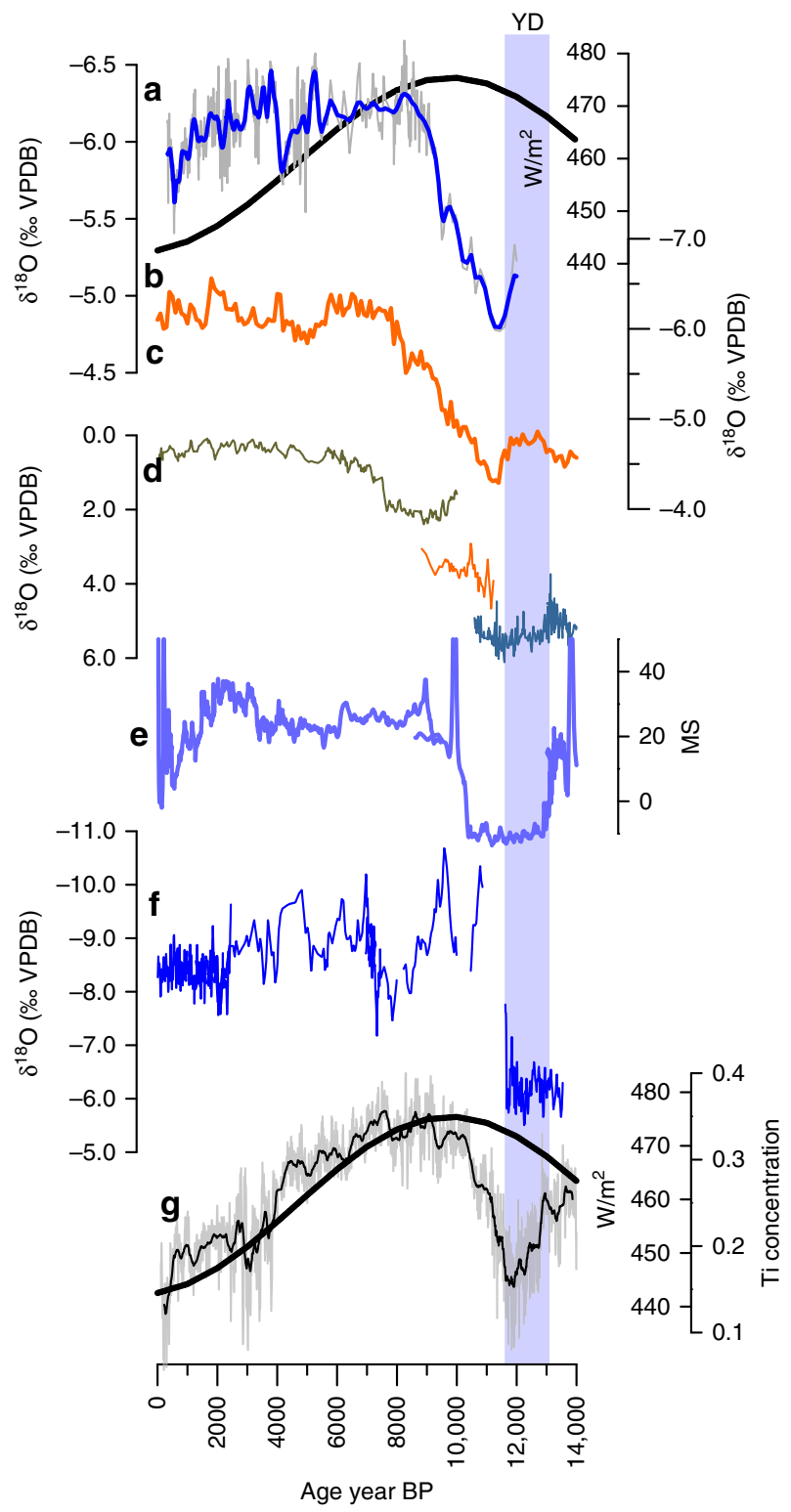

Fig. 2 Comparison of Central American and regional rainfall records. a Guatemala (GU-RM1) $\delta^{18} \mathrm{O}$ (proxy for precipitation). b $15^{\circ} \mathrm{N}$ insolation for Jul 21. c Lake Petén Itza $\delta^{18} \mathrm{O}$ (proxy for precipitation) from three different locations in the basin $26,67,68$. d The $\delta^{18} \mathrm{O}$ (proxy for precipitation) record from Juxtlahuaca and Diablo Caves ${ }^{9}$, Mexico. e Petén Itza magnetic susceptibility (environmental finger printing) 7,26 . f Juxtlahuaca cave, Mexico ${ }^{69} \cdot \mathbf{g}$ Cariaco Basin titanium concentration (hydrological input) record 28 and July 21 insolation at $15^{\circ} \mathrm{N}$.

(Mexico) which respond to a mix of orbital and ocean circulation pacing (Fig. 2d). Similarly, the monsoon over southwestern Mexico $^{9}$ appears to have strengthened by ca. 11,000 yr BP after the aridity of the Younger Dryas (Fig. 2f), possibly linked to the resumption of the Atlantic Meridional Overturning Circulation (AMOC), suggesting that the forcings there differ from those in Guatemala.

The GU-RM1 record spanning the whole Holocene provides a new perspective on Central American hydroclimate evolution and confirms that Central America transitioned into a wet regime similar to the modern one no earlier than $9000 \mathrm{yr}$ BP, following by more than a millennium the cessation of gypsum deposition indicating arid conditions in Lake Petén Itzá at around 10,300 $\mathrm{BP}^{29}$. The wet regime has persisted ever since, while at the same 
time undergoing multicentennial to millennial-scale variations. The different reconstructed rainfall evolution highlights the marked hydroclimatic heterogeneity of the Central American region.

Evidence of deglaciation forcing and oceanic circulation. The transition from a dry regime to the early Holocene wet regime in the GU-RM1 record between $\sim 11,000$ and $9000 \mathrm{yr}$ BP follows the late phase of quickly retreating ice sheets. This period was associated with a strengthening of the AMOC, increase in Caribbean $\mathrm{SSTs}^{30,31}$, and warming land surface temperatures ${ }^{7,32}$ (Fig. 3). Indeed, the time of peak AMOC strength at $8400 \mathrm{yr}$ PB changes synchronously (within age model uncertainties) of peak rainfall amount at $8400 \mathrm{yr}$ BP as inferred from the lowest GU-RM1 $\delta^{18} \mathrm{O}$ values. Further, the Caribbean SST warming is part of a larger surface ocean warming in the tropical North Atlantic as shown by

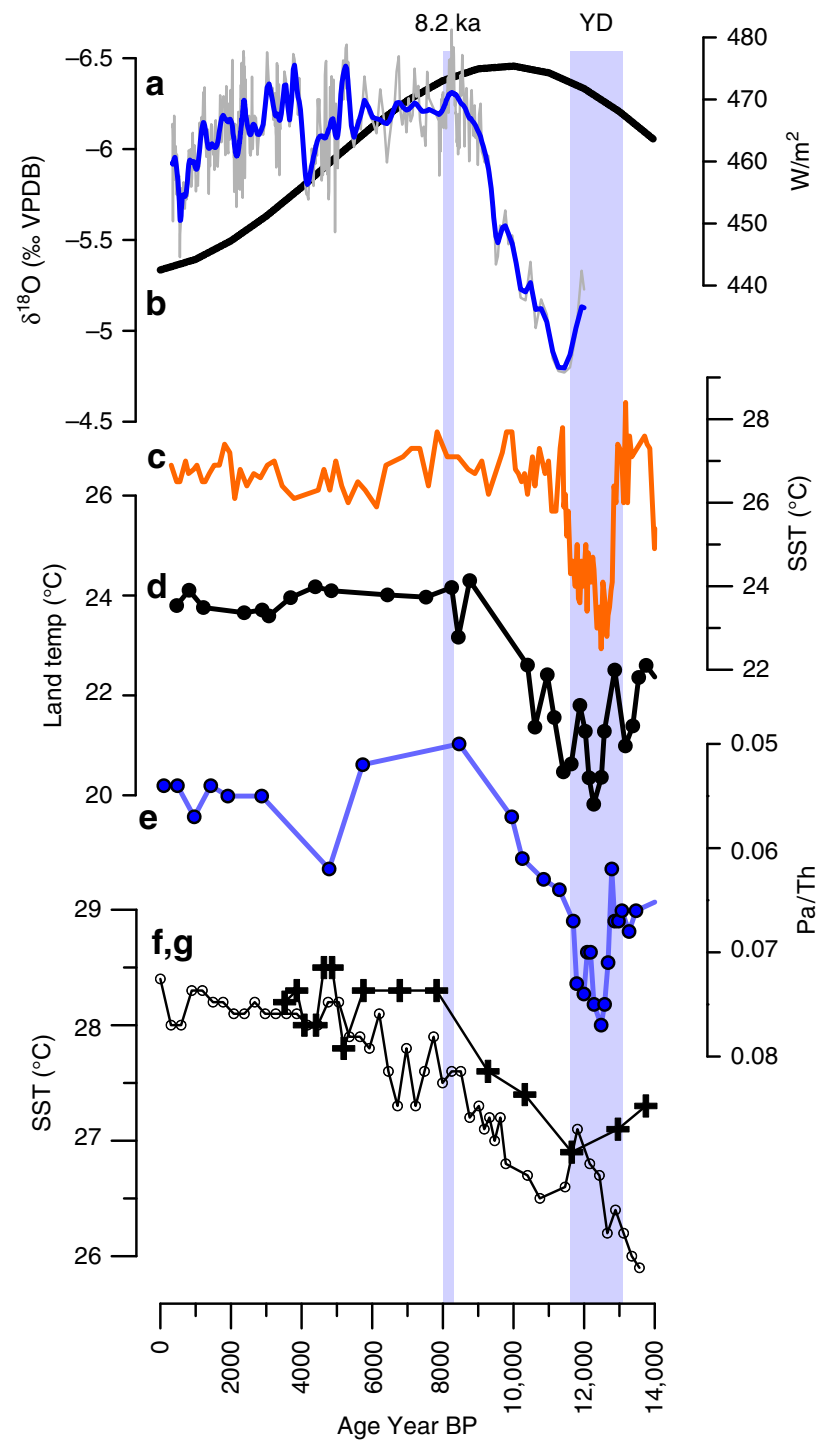

Fig. 3 Ocean-atmosphere linkages to the Holocene rainfall increase. Comparison of $\mathbf{a}$ the Guatemala speleothem GU-RM1 precipitation proxy with b $15^{\circ} \mathrm{N}$ July 21 insolation, c sea-surface temperature (SST) in the Cariaco Basin from $\mathrm{Mg} / \mathrm{Ca}$ proxy ${ }^{57}$, $\mathbf{d}$ the inferred land surface temperature for the Petén region of Guatemala from pollen in Lake Petén Itza sediments ${ }^{7}$, and $\mathbf{e}$ the $\mathrm{Pa} / \mathrm{Th}_{\text {ratio }}{ }^{70}$, a proxy for the strength of the Atlantic Meridional Overturning Circulation (AMOC), f the SST near Grenada ${ }^{33}$ (gray line with circles), and $\mathbf{g}$ Caribbean SST ${ }^{32}$ (black line with crosses).
SST reconstructions from the eastern part of the basin (Fig. 3f) and by indications of early post-glacial warming in reconstructions of Gulf of Mexico SSTs ${ }^{33,34}$.

We thus posit that Caribbean SST and land surface warming was manifested as the basin-scale response to a more vigorous AMOC. Variations in the strength of the AMOC are linked to meridional redistributions of ocean heat within the North Atlantic whose SST spatial pattern superposes on that of the Atlantic Multidecadal Oscillation (AMO) $)^{35,36}$. The AMO is a mode of natural climate variability that consists of the multidecadal alternation between warm and cold phases of North Atlantic average SST anomalies ${ }^{37}$, which are known to entail surface warming and cooling of the inter-American Seas ${ }^{38}$. Reconstructions of multidecadal climate oscillations suggest that AMO-like variability existed during large parts of the Holocene ${ }^{39}$. A tight connection between AMO variability and Central American rainfall has been shown to hold during the last $\sim 2.5$ centuries $^{8}$ and seems to be active as well on longer (millennial and longer) time scales ${ }^{40}$. The nature of the AMO as a predominantly oceanic rather than atmospherically forced phenomenon remains debated ${ }^{41-44}$. Notwithstanding uncertainties in the AMO nature and characteristic time scales, we build on the AMO paradigm to better understand the possible nearsurface dynamics contributing to basin-average North Atlantic SST changes and Caribbean hydroclimate variations in the early Holocene, i.e., we do not claim that AMO necessarily explainsbut is a useful analog for-the early Holocene regime shift for Caribbean rainfalls.

Accordingly, idealized AMO climate simulations ${ }^{45}$ yielding peak warm-minus-cold differences in Caribbean SSTs comparable to reconstructed estimates of post-glacial warming result in a broad precipitation increase over the Caribbean region. This is particularly linked to the development of a near-surface negative pressure anomaly in the western tropical Atlantic that weakens the climatological flow as evidenced by the westerly wind anomalies in the Caribbean low-level jet core region (Fig. 4). Such interpretation is consistent with wetting over the Yucatan based on arguments about moisture divergence ${ }^{46,47}$. Other climate simulations further show that changes in the extent of Northern Hemisphere's ice sheets are associated with changes in inter-hemispheric temperature gradients, in turn driving meridional ITCZ shifts through modified tropical-midlatitude atmospheric bridges and associated heat transport ${ }^{48}$. The reconstructed change in the Central American precipitation regime is linked to warming of Caribbean SSTs as part of a basinscale, AMOC-driven warming of the upper North Atlantic with a spatial pattern like the one characterizing modern multidecadal SST variability. We thus attribute increased rainfall amounts to surface ocean warming in the Caribbean Sea, which is the dominant moisture source feeding rainfall at the GU-RM1 site, associated with the invigoration of AMOC following the decay of the Laurentide Ice Sheet. Aspects of the mechanisms linking AMOC, SST, and Caribbean rainfall remain to be understood, particularly regarding the quantifications of time lags.

Regional dynamic interpretation. With the culmination of the Laurentide ice sheet melting around $8000 \mathrm{yr}$ BP, SST warming in the tropical North Atlantic contributed to further northward extension of the area under the influence of the ITCZ. The SST warming and the ITCZ shift led to increasingly stronger atmospheric convective activity over Central America, until a critical threshold was reached to persistently include Guatemala at around $9000 \mathrm{yr} \mathrm{BP}$. In contrast to regions within the core of the ITCZ, such as the Cariaco basin $\left(10^{\circ} \mathrm{N}\right)$, which predominantly experienced changes in rainfall intensity, areas at the edge of the 
a

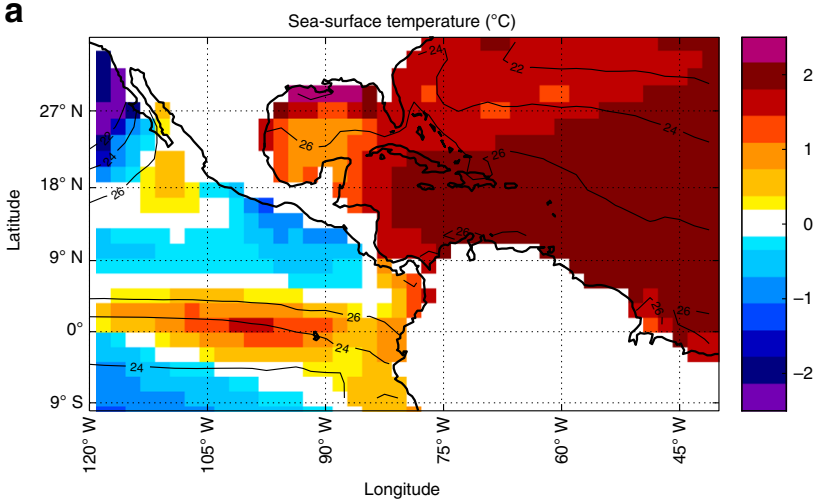

C

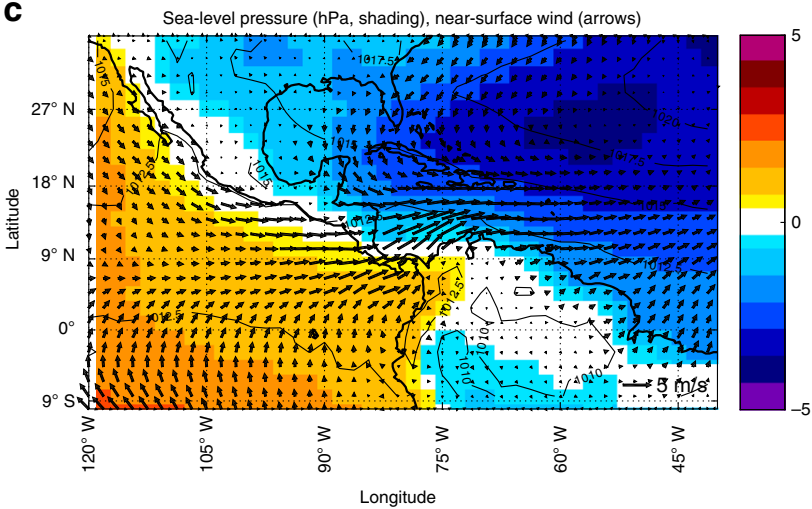

b

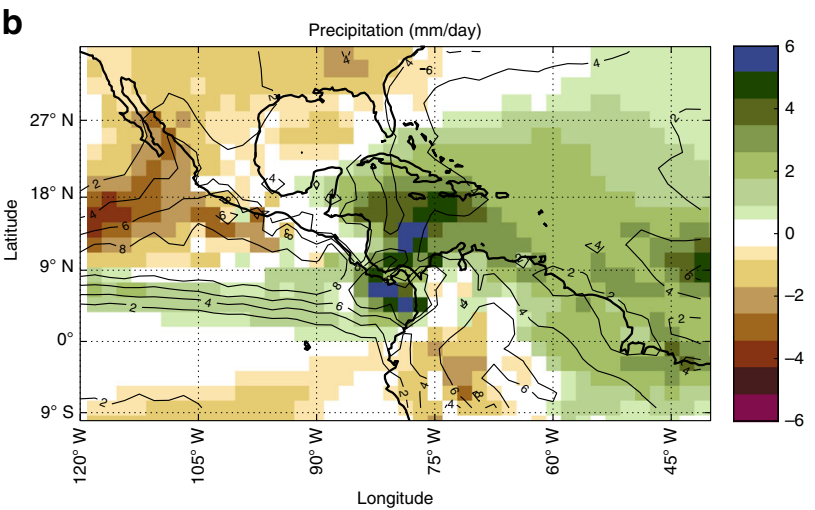

d

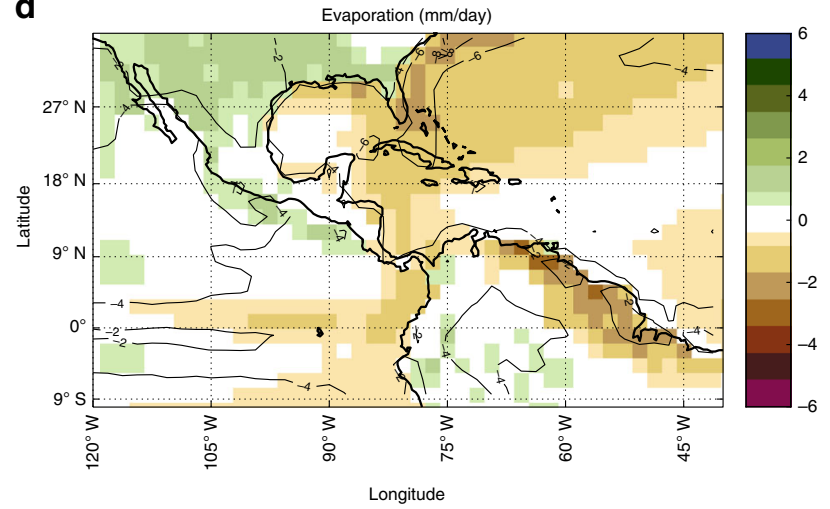

Fig. 4 Climate anomalies with a $\sim \mathbf{2}^{\circ} \mathbf{C}$ tropical Atlantic SST warming. Idealized simulation with the Max Plank Institution for Meteorology Earth System Model. Shadings are anomalies in sea-surface temperature (a), precipitation (b), sea-level pressure (c), and evaporation (d) between peak warm Atlantic Multidecadal Oscillation (AMO) and peak cold AMO anomalies from six idealized 70-year sinusoidal AMO cycles; line contours identify the associated climatologies (see ref. ${ }^{45}$ for details). Arrows in panel $\mathbf{c}$ represent warm-cold differences in $10 \mathrm{~m}$ winds. Peak warm and peak cold values are determined as 11-year averages around the warmest and coldest year in each AMO cycle, respectively.

ITCZ experienced a transition from a predominantly nonconvective to a predominantly convective regime. This is an important difference since the rainfall proxy record from Cariaco cannot be seen as representative of the broad rainfall evolution over Central America. Our data also provide long-term context to the hydroclimatic variations during the late Holocene that may have impacted ancient indigenous Mesoamerican societies such as the Olmecs and the Maya ${ }^{49}$ : such variations occurred within the general stability of the hydroclimatic wet regime and are much smaller than the dry-to-wet transition during the early Holocene. However, relatively small variations in rainfall have been shown to impact past societal responses to climate change $\mathrm{e}^{50}$, suggesting that future rainfall change within the active convective regime may also have significant societal effects ${ }^{51}$.

Within a simplified dynamical framework, the mean value of reconstructed Caribbean SST after the early Holocene transition remains around the estimated critical SST threshold of $\sim 27.5^{\circ} \mathrm{C}$ needed to trigger atmospheric deep convection in the tropics ${ }^{52}$. However, the covariation between tropical-mean SSTs and the convective threshold revealed by satellite data ${ }^{53}$ suggests that such a threshold depends, to some extent, on the background climate conditions, and it might have been lower than for present-day climates in the early post-glacial era. A faunal record of SST variations off West Africa ${ }^{54}$ reveals a major warming of $\sim 2{ }^{\circ} \mathrm{C}$ around $5000 \mathrm{yr} \mathrm{BP}$, which might have implications for the evolution of Central American precipitation, as the GU-RM1 and Cariaco records diverge most noticeably following such transition.

We conclude that precipitation on the Caribbean slope of Central America was not predominantly affected by insolation but by a change in the convective regime associated with the disappearance of the Laurentide Ice Sheet and strengthening of the AMOC, leading to a broad warming in the tropical North Atlantic and ultimately a broadening of the area under the ITCZ influence. In glacial times, relatively cold Caribbean SSTs (as low as $23{ }^{\circ} \mathrm{C}$, see Fig. $3 \mathrm{~g}$ ) could not sustain vigorous convective activity in the Guatemalan region, whereas SST warming during the glacial-interglacial transition and persistent warm SST conditions through the Holocene favored increased convective activity there, and a decrease in rainfall $\delta^{18} \mathrm{O}$ values. Reconstructed SSTs in the Cariaco basin underwent a sharp warming to reach $\sim 27^{\circ} \mathrm{C}$ around 10,000 years ${ }^{55}$, i.e., before the onset of an active hydrological regime in our record and maximum rainfallinduced runoff to the Cariaco Basin at $\sim 9000 \mathrm{yr}$ BP (Fig. 3c). Quantification of the lag between both events requires narrowing and more robustly constraining age model uncertainties.

In summary, the Guatemalan GU-RM1 speleothem record reveals crucial information about the evolution of Central American rainfall throughout the Holocene and sheds light on dominant dynamics underlying hydroclimate variability in the area, particularly concerning its sensitivity to external forcing. Our study shows that Central American rainfall as inferred by the Guatemalan GU-RM1 speleothem record underwent an "off-on" switch between 11,000 and $9000 \mathrm{yr}$ BP. This increase in precipitation at the GU-RM1 site was likely enhanced by AMOC recovery, which contributed to SST warming in the Caribbean Sea and northward shift of the ITCZ, bringing the pool of atmospheric moisture in closer proximity to Guatemala, to which it supplied convective systems over land. The exceedance of an SST threshold in the nearby tropical ocean triggered deep 
atmospheric convection, hence a dry-to-wet regime shift over Central America. Paleoclimate records from the Cariaco basin indicate that weakening of summer insolation during the middle and late Holocene led to a gradual southward retreat of the ITCZ. However, our results suggest that the Central American rainfall did not exhibit a large decrease directly following changes in the insolation forcing but remained strong due to the convective activity favored by persisting warm SSTs in the Caribbean Sea. Further, our results support recent model-based evidence of a significant role of the AMOC in the modulation of externally forced latitudinal ITCZ shifts ${ }^{56}$.

From this speleothem record the Central American hydroclimate emerges as strongly linked to SST variability in the Caribbean and tropical North Atlantic. The association between Central American rainfall variability and basin-scale oceanic changes in the North Atlantic seen on multidecadal-to-centennial time scales for the past 1200 years $^{36}$ thus appears to hold also on Holocene time scales. Our work is also intended to stimulate further research to characterize and understand hydroclimate variability in a narrow land bridge of strong topographic heterogeneity at the boundary between two major ocean basins. These differences stress the need to surpass the simplistic perception of tropical hydroclimates being summarized as a stronger global monsoon in the early- to mid-Holocene compared to the present. Finally, as our results highlight, the dependency of the Central American rainfall on the overturning circulation in the Atlantic Ocean will crucially affect, together with atmospheric circulation changes ${ }^{47,57}$, the future Central American hydroclimate regime.

\section{Methods}

Stalagmite specimen. The stalagmite GU-RM1 was collected on 8 August 2011 at Grutas del Rey Marcos (Supplementary Fig. 1), located about $20 \mathrm{~km}$ southeast of the city of Cobán, Guatemala. Handheld GPS gives a location of $15.42769^{\circ} \mathrm{N}$ and $-90.28066^{\circ} \mathrm{W}$, at an elevation of $1460 \mathrm{~m}$ asl. The area is temperate and damp yearround, with a high-altitude tropical forest covering the region of the cave, with a mean annual precipitation of $2300 \mathrm{~mm}$ and a temperature of $18^{\circ} \mathrm{C}$. Mean monthly relative humidity is above $80 \%$ in the wet season, dropping to $~ 75 \%$ during the March-April dry season. Stalagmite GU-RM1 was recovered $50 \mathrm{~m}$ inward from the cave entrance past a narrow constriction in the first main passage. Although the surface of the stalagmite was damp, indicating $100 \%$ relative humidity and later verified by in-cave measurements in March 2019, the drip rate at the stalagmite location was too slow at time of sampling to collect drip water samples, or to verify the sample was actively growing; the U/Th data suggest a tip age from $1.3 \mathrm{~mm}$ depth of $411 \mathrm{yr}$ BP, possibly indicating inactive growth during collection because we would expect an age closer to $100 \mathrm{yr}$ BP. Rey Marcos cave contains other calcite stalagmites up to several meters in height, which could provide evidence of hydrological changes over several glacial-interglacial cycles. Ongoing cave monitoring was recently initiated in March 2019 to provide cave climate, drip rate, and drip water $\delta^{18} \mathrm{O}$ values; these data will be included in future work.

Stalagmite GU-RM1 has a depressed drip dish flanked by a raised rim similar to many stalagmites we have worked with (Supplementary Fig. 2); the rim is likely formed when the drip impact causes a splash away from the impact point. The milling transect was oriented vertically along the right-hand rim to maintain sample continuity and to avoid calcite in the drip dish, which has less visible banding than along the rim. The precise center of the growth axis moved off the milling axis for some portions of growth. Our experience with other similar stalagmites in humid tropical caves is that isotope values are relatively constant along layers near the growth axis, so that such changes in location are unlikely to have a significant influence on the measured $\delta^{18} \mathrm{O}$ and $\delta^{13} \mathrm{C}$ values. Evaluation of Supplementary Fig. 2 shows that there is no clear isotopic anomaly associated with where our milling transect departs from the central growth axis $(\sim 45-90 \mathrm{~mm}$ depth), indicating that the isotope data are not influenced by drilling location. However, to test this idea more rigorously, we repeated drilling transects to more closely follow the center of the growth axis (to the side of the drip dish). Supplementary Figure 3 shows that transect location relative to the central growth axis results in the same decrease in from the two different transects meet the null hypothesis that they come from a population with the same mean, as determined by a two-sample $t$-test.

Age model. An amount of $\sim 200 \mathrm{mg}$ of powder was collected with a handheld dental drill from a polished central slab section of GU-RM1 along growth layers for MC-ICPMS ${ }^{230} \mathrm{Th} / \mathrm{U}$-dating. Twenty-one ${ }^{230} \mathrm{Th} / \mathrm{U}$ dates were analyzed in the upper $117 \mathrm{~mm}$ resulting in an age control point approximately every 600 years (Fig. 1b). Sample depths were determined by digitizing a high-resolution image to provide precise mid-point depths. Dates were obtained with a magnetic sector multi-collector inductively coupled plasma mass spectrometer at the Universities of Minnesota and Xi'an Jiaotong (China), following routine instrumental procedures and $^{58,59}$ chemical separation ${ }^{60}$.

U-series ages for stalagmite GU-RM1 are in correct stratigraphic order (except for around 67 and $77 \mathrm{~mm}$ depth) and show precise U-Th dates (median two sigma age uncertainty is \pm 132 years). The high dating precision arises from the high $\delta^{234} \mathrm{U}$ values $\left(>450 \%\right.$ o) and a minor contribution of detrital ${ }^{230} \mathrm{Th}$, resulting in small age corrections ( $<70$ years). The robust age/depth progression suggests little to no secondary alteration or post-depositional mobilization of uranium. Two dates near the base are identical within age error $(113.6$ and $116.8 \mathrm{~mm}$, Supplementary Table 1), so we have elected to use in the age model only the $116.8 \mathrm{~mm}$ age $(11,320$ $\pm 247 \mathrm{yr}$ BP) because it has the lower uncertainty. Additionally, one section shows an age inversion, of either the 67 or $77 \mathrm{~mm}$ samples. We chose to exclude the sample at $67 \mathrm{~mm}$ depth from the age model, although it remains plotted in Fig. 1, because it had larger age uncertainty $(5710 \pm 214 \mathrm{yr} \mathrm{BP})$ compared to the more precise age at $77 \mathrm{~mm}$ depth $(5328 \pm 91 \mathrm{yr} \mathrm{BP})$. The age constraints over the $\sim 65-80$ $\mathrm{mm}$ interval are thus potentially weaker than at other sections of the stalagmite; a sensitivity test to swap in the $67 \mathrm{~mm}$ age and swap out the $77 \mathrm{~mm}$ age in the modeling routine suggests a difference in ages of $<500$ years for this depth interval compared to the age model used in this paper, although it does not affect the overall conclusion of the paper. Future replication with other stalagmites may resolve the discrepancy.

The age model for the speleothem is calculated using the COPRA algorithm ${ }^{61}$ based on the ${ }^{230} \mathrm{Th} / \mathrm{U}$ dates and distance from the top using a Monte Carlo simulation of 2000 possible age models. The age model uncertainty

(Supplementary Fig. 2) was estimated from the COPRA Monte Carlo age/depth simulations and is mostly better than \pm 400 years. We show in each plot (Figs. 1-3, panel a) both the COPRA output time series (bold blue lines) that accounts for age model uncertainty, and the age assignment to each measured $\delta^{18} \mathrm{O}$ subsample (thin blue line). We focus our discussion on the post-Younger Dryas interval, because our age model is not robust for the oldest sections of the stalagmite.

Finally, the GU-RM1 stalagmite was slow-growing $(0.012 \mathrm{~mm} / \mathrm{yr}$ over the last $\sim 11,000$ years). Such slow growth in warm humid tropical caves is unusual and provide a unique opportunity to constrain a Holocene-length climate record as many other stalagmites from the humid tropics have growth rates one to two orders of magnitude faster than GU-RM1 and span shorter time intervals. We consider that this specific stalagmite was possibly beneath a slow but continuous drip, which allowed growth much slower than typically seen for such wet climates. We will further test this idea by the collection of additional material from the cave in future visits.

Local climatology. The central Guatemala highlands currently features a hydroclimate regime characterized by a boreal summer/fall rainy season and a relatively dry winter ${ }^{8,62}$. This annual rainfall cycle is largely determined by the seasonal migration of the ITCZ, whose northernmost position in boreal summer currently reaches Mesoamerica (Supplementary Fig. 5), by the summer intensification of the easterly Caribbean low-level jet determining an increased moisture transport and precipitation over Central America, and by topographic effects. The stalagmite most likely reflects wet season recharge, as suggested by drip water observations in a Yucatán lowland cave 23 .

Isotopic analysis. A Sherline 5410 mill was used to continuously mill powder samples near the growth axis for stable isotope analysis at a resolution of $0.1-0.5$ $\mathrm{mm}$ (Supplementary Fig. 6). The subsampling intervals result in a median sample resolution of 12 years, with the majority $(83 \%)$ of the samples having an age resolution better than 40 years, and $69 \%$ of the samples having a resolution better than 20 years based on the COPRA age model output (Fig. 1). Stalagmite $\delta^{18} \mathrm{O}$ values were determined on a Kiel IV automated carbonate preparation device via phosphoric acid digestion at $70^{\circ} \mathrm{C}$ connected to a ThermoElectron Delta V Plus mass spectrometer. Samples were corrected to an in-house calcite standard that was calibrated to NBS-19 and NBS-18 standards and reported relative to the VPDB (Vienna PeeDee Belemnite) international standard. Precision on $\delta^{18} \mathrm{O}$ is better than $\pm 0.08 \%$ and for $\delta^{13} \mathrm{C}$ is $\pm 0.06 \%$. The analysis was conducted at the Las Vegas Isotope Science Laboratory at the University of Nevada Las Vegas. The lack of $\delta^{18} \mathrm{O} / \delta^{13} \mathrm{C}$ covariation (Supplementary Fig. 4) over the Holocene indicates that kinetic fractionation is not a strong control on stable isotope values. To further test this idea, we estimated the drip water $\delta^{18} \mathrm{O}$ value using the cave temperature measured on 22 and 23 March 2019 of $17.6^{\circ} \mathrm{C}$ and our uppermost calcite sample with a $\delta^{18} \mathrm{O}$ value of $-6.1 \%$ VPDB. This sample likely does not represent modern calcite precipitation, because the top Useries age at $1.3 \mathrm{~mm}$ returned an age of $411 \pm 57 \mathrm{yr} \mathrm{BP}$ but is used because it is the most recent available. The corresponding equilibrium $\delta^{18} \mathrm{O}$ value of the drip is $-7.0 \%$ VSMOW using the most up to date calcite-water fractionation equation ${ }^{63}$. These data compare to $\delta^{18} \mathrm{O}$ values of nearby rivers of $-6.6 \%$ VSMOW (Rio Tzunutz) and $-6.45 \%$ VSMOW (Rio Cahabón), which are typical for that location and altitude in Guatemala ${ }^{64}$ (Supplementary Fig. 1). We also completed three along-layer sampling transects (Supplementary Fig. 4); 
these data show no significant $\delta{ }^{18} \mathrm{O}$ increase away from the growth axis at depths of $0,52.5$, and $116 \mathrm{~mm}$. These data suggest that kinetic isotope effects were not a controlling factor for the $\delta^{18} \mathrm{O}$ and $\delta^{13} \mathrm{C}$ values along individual growth layers. Combined, these data suggest that GU-RM1 was precipitated at or near isotopic equilibrium with regional annual precipitation. The damp stalagmite surface, high regional humidity, and apparent isotopic equilibrium between stalagmite calcite $\delta^{18} \mathrm{O}$ and nearby waters suggest that kinetic fractionation is not an important control on calcite $\delta^{18} \mathrm{O}$.

Climate model and idealized AMO simulations. The Max Planck Institute Earth system model for paleo-applications includes the atmospheric general circulation model ECHAM6 in its T63L47 configuration (corresponding to a longitudinal grid spacing of about $190 \mathrm{~km}$ at the tropics) and the ocean-sea ice model MPIOM in its GR15L40 configuration ${ }^{65}$. This climate model has been extensively studied regarding the characteristics of the AMO and its atmospheric teleconnections ${ }^{35}$ and its link with ocean dynamics in the equatorial Pacific ${ }^{45}$. When coupled, ECHAM6 is affected by a systematic bias in the partitioning of precipitation between land and sea in tropical regions compared to observations ${ }^{66}$. The idealized simulation employed here features 70-year long sinusoidal AMO oscillations that are imposed to the model via pattern nudging applied on upper-ocean potential temperature field in the North Atlantic basin ${ }^{45}$. Five consecutive AMO oscillations with a maximum amplitude of about $2^{\circ} \mathrm{C}$ are simulated starting from a millennial control run. Further information about the nudging procedure and the simulation is provided in ref. ${ }^{45}$. Due to the rather coarse model resolution and associated biases, we only focus on large-scale changes and avoid interpreting local features in Central America.

\section{Data availability}

The GU-RM1 data reported in this paper have been deposited in the cave section of the paleoclimatology data sets: https://www.ncdc.noaa.gov/paleo/study/28351

Received: 2 July 2018; Accepted: 16 December 2019;

Published online: 05 February 2020

\section{References}

1. Wang, P. X., et al. The global monsoon across time scales: mechanisms and outstanding issues. Earth-Sci. Rev. 174, 84-121 (2017).

2. Giannini, A., Kushnir, Y. \& Cane, M. A. Interannual variability of Caribbean rainfall, ENSO, and the Atlantic Ocean. J. Clim. 13, 297-311 (2000).

3. Denniston, R. F. et al. A Stalagmite record of Holocene Indonesian-Australian summer monsoon variability from the Australian tropics. Quat. Sci. Rev. 78, 155-168 (2013).

4. Lachniet, M. S. et al. Late Quaternary moisture export across Central America and to Greenland: evidence for tropical rainfall variability from Costa Rican stalagmites. Quat. Sci. Rev. 28, 3348-3360 (2009).

5. Carolin, S. A. et al. Varied response of western Pacific hydrology to climate forcings over the last glacial period. Science 340, 1564-1566 (2013).

6. Griffiths, M. L. et al. Increasing Australian-Indonesian monsoon rainfall linked to early Holocene sea-level rise. Nat. Geosci. 2, 636-639 (2009).

7. Hodell, D. A. et al. An 85 -ka record of climate change in lowland Central America. Quat. Sci. Rev. 27, 1152-1165 (2008).

8. Winter, A. et al. Persistent drying in the tropics linked to natural forcing. Nat. Commun. 6, 7627 (2015).

9. Lachniet, M. S., Asmerom, Y., Bernal, J. P., Polyak, V. J. \& Vazquez-Selem, L. Orbital pacing and ocean circulation-induced collapses of the Mesoamerican monsoon over the past 22,000 y. Proc. Natl Acad. Sci. USA 110, 9255-9260 (2013).

10. Bernal, J. P. et al. A speleothem record of Holocene climate variability from southwestern Mexico. Quat. Res. 75, 104-113 (2011).

11. Castro, C. L., McKee, T. B. \& Pielke Sr., R. A. The relationship of the North American Monsoon to tropical and North Pacific sea surface temperatures as revealed by observational analyses. J. Climate 14, https://doi.org/10.1175/ 1520-0442(2001)0143E2.0.CO;2 (2001).

12. Magaña, V. O., Vázquez, J. L., Pérez, J. L. \& Pérez, J. B. Impact of El Niño on precipitation in Mexico. GeofíSci. Int. 42, 313-330 (2003).

13. Fuentes-Franco, R. et al. Inter-annual variability of precipitation over Southern Mexico and Central America and its relationship to sea-surface temperature from a set of future projections from CMIP5 GCMs and RegCM4 CORDEX simulations. Clim. Dyn. 45, 425-440 (2015).

14. Douglas, P. M. J., Demarest, A. A., Brenner, M. \& Canuto, M. A. Impacts of climate change on the collapse of Lowland Maya Civilization. Ann. Rev. Earth Planet. Sci. 44, 613-645 (2016).

15. Evans, N. P. et al. Quantification of drought during the collapse of the classic Maya civilization. Science 361, 498-501 (2018).
16. Liu, Z. Dynamics of interdecadal climate variability: a historical perspective. J. Clim. 25, 1963-1995 (2012).

17. Ljungqvist, F. C. et al. Northern hemisphere hydroclimatic variability over the past twelve centuries. Nature 532, 94-98 (2016).

18. Christensen, J. H., et al. (eds) Climate Change: The Physical Science Basis. Contribution of Working Group I to the Fifth Assessment Report of the Intergovernmental Panel on Climate Change (Cambridge University Press, Cambridge, UK and New York, NY, USA, 2013).

19. Kavvada, A., Ruiz-Barradas, A. \& Nigam, S. AMO's structure and climate footprint in observations and IPCC AR5 climate simulations. Clim. Dyn. 41, 1345-1364 (2013).

20. Zou, Y., Yu, J.-Y., Lee, T., Lu, M.-M. \& Kim, S. T. CMIP5 model simulations of the impacts of the two types of El Niño on the U.S. winter temperature,. J. Geophys. Res. Atmos. 119, 3076-3092 (2014).

21. Liu, Y. et al. Potential impact of climate change on the Intra-Americas Sea: Part-1. A dynamic downscaling of the CMIP5 model projections. J. Mar. Syst. 148, 56-69 (2015)

22. Lachniet, M. S. \& Patterson, W. P. Use of correlation and multiple stepwise regression to evaluate the climatic controls on the stable isotope values of Panamanian surface waters. J. Hydrol. 324, 115-140 (2006).

23. Lases-Hernandez, F., Medina-Elizalde, M., Burns, S. \& DeCesare, M. Longterm monitoring of drip water and groundwater stable isotopic variability in the Yucatán Peninsula: implications for recharge and speleothem rainfall reconstruction. Geochim. Cosmochim. Acta 246, 41-59 (2019).

24. Escobar, J. et al. A 43-ka record of paleoenvironmental change in the Central American lowlands inferred from stable isotopes of lacustrine ostracods. Quat. Sci. Rev. 37, 92-107 (2012).

25. Leyden, B. W., Brenner, M., Hodell D. A. \& Curtis J. H. Late Pleistocene climate in the Central American lowlands. In: Climate Change in Continental Isotopic Records. American Geophysical Union Geophysical Monograph, Vol. 78 (eds. Swart, P. K., Lohmann, K. C., McKenzie, J. \& Savin, S.) (Washington, DC, USA, 1993).

26. Haug, G. H., Hughen, K. A., Sigman, D. M., Peterson, L. C. \& Roehl, U. Southward migration of the Intertropical Convergence Zone through the Holocene. Science 293, 1304-1308 (2001).

27. Hughen, K., Southon, J., Lehman, S., Bertrand, C. \& Turnbull, J. Marinederived $14 \mathrm{C}$ calibration and activity record for the past 50,000 years updated from the Cariaco Basin. Quat. Sc. Rev. 25, 3216-3227 (2006).

28. Kanner, L. C. et al. High-resolution variability of the South American summer monsoon over the last seven millennia: insights from a speleothem record from the central Peruvian Andes. Quat. Sc. Rev. 75, 1-10 (2013).

29. Bush, M. B. et al. In Past Climate Variability in South America and Surrounding Regions: From the Last Glacial Maximum to the Holocene (eds. Vimeux, F., Sylvestre, F. \& Khodri, M.) 113-128 (Springer, Dordrecht, Netherlands, 2009)

30. Schmidt, M. W., Vautravers, M. J. \& Spero, H. J. Western Caribbean sea surface temperatures during the late Quaternary. Geochem. Geophys. Geosyst. 7, 1-17 (2006).

31. Rühlemann, C. et al. Warming of the tropical Atlantic Ocean and slowdown of thermohaline circulation during the last deglaciation. Nature 402, 511-514 (1999).

32. Correa-Metrio, A. et al. Rapid climate change and no-analog vegetation in lowland Central America during the last 86,000 years. Quat. Sci. Rev. 38, 63-75 (2012).

33. LoDico, J. M., Flower B. P., \& Quinn, T. M. Subcentennial-scale climatic and hydrologic variability in the Gulf of Mexico during the early Holocene. Paleoceanography. 21, PA3015 (2006).

34. Williams, C. et al. Deglacial abrupt climate change in the Atlantic warm pool: a Gulf of Mexico perspective. Paleoceanography 25, PA4221 (2010).

35. Zanchettin, D., Bothe, O., Müller, W., Bader, J. \& Jungclaus, J. H. Different flavors of the Atlantic multidecadal variability. Clim. Dyn. 42, 381-399 (2014).

36. Zhang, J. \& Zhang, R. On the evolution of the Atlantic Meridional Overturning Circulation Fingerprint and implications for decadal predictability in the North Atlantic. Geophys. Res. Lett. 42, 5419-5426 (2015).

37. Enfield, D. B., Mestas-Nuñez, A. M. \& Trimble, P. J. The Atlantic multidecada oscillation and its relation to rainfall and river flows in the continental US. Geophys. Res. Lett. 28, 2077-2080 (2001).

38. del Monte-Luna, P., Villalobos, H. \& Arreguín-Sánchez, F. Variability of sea surface temperature in the southwestern Gulf of Mexico. Cont. Shelf Res. 102, 73-79 (2015).

39. Knudsen, M. F., Seidenkrantz, M. S., Jacobsen, B. H. \& Kuijpers, A. Tracking the Atlantic multidecadal oscillation through the last 8,000 years. Nat. Commun. 2, 178 (2011)

40. Bhattacharya, T., Chiang, J. C. H. \& Cheng, W. Ocean-atmosphere dynamics linked to 800-1050 CE drying in mesoamerica. Quat. Sci. Rev. 169, 263-277 (2017).

41. Clement, A. et al. The Atlantic multidecadal oscillation without a role for ocean circulation. Science 350, 320-324 (2015). 
42. Zhang, R. et al. Comment on: the Atlantic multidecadal oscillation without a role for ocean circulation. Science 352, 1527 (2016).

43. Clement, A., et al. Response to comment on the Atlantic multidecadal oscillation without a role for ocean circulation. Science 352, https://doi.org/ 10.1126/science.aaf2575 (2015).

44. Zhang, R. On the persistence and coherence of subpolar sea surface temperature and salinity anomalies associated with the Atlantic multidecadal variability. Geophys. Res. Lett. 44, 7865-7875 (2017).

45. Zanchettin, D., et al. A decadally delayed response of the tropical Pacific to Atlantic multidecadal variability. Geophys. Res. Lett. 43, 784-792 (2016).

46. Wang, C., Lee, S. K. \& Enfield, D. B. Climate response to anomalously large and small Atlantic warmpools during the summer. J. Clim. 21, 2437-2450 (2008).

47. Mestas-Nuñez, A. M., Enfield, D. B. \& Zhang, C. Water vapor fluxes over the Intra-Americas Sea: seasonal and interannual variability and associations with rainfall. J. Clim. 20, 1910-1922 (2007).

48. Broccoli, A. J., Dahl, K. A. \& Stouffer, R. J. Response of the ITCZ to Northern Hemisphere cooling. Geophys. Res. Lett. 33, 1 (2006).

49. Demarest, A. Ancient Maya: The Rise and Fall of a Rainforest Civilization Vol. 3 (Cambridge University Press, 2004).

50. Medina-Elizalde, M. \& Rohling, E. J. Collapse of classic Maya civilization related to modest reduction in precipitation. Science 335, 956-959 (2012).

51. Kennett, D. J. et al. Development and disintegration of maya political systems in response to climate change. Science 338, 788-791 (2012).

52. Evans, J. L. \& Webster, C. C. A variable sea surface temperature threshold for tropical convection. Aust. Meteorol. Oceanogr. J. 64, S1-S8 (2014).

53. Johnson, N. C. \& Xie, S. P. Changes in the sea surface temperature threshold for tropical convection. Nat. Geosci. 3, 842-845 (2010).

54. deMenocal, P. B., Ortiz, J., Guilderson, T. \& Sarnthein, M. Coherent high-and low-latitude climate variability during the Holocene warm period. Science 288, 2198-2202 (2000).

55. Lea, D. W., Pak, D. K., Peterson, L. C. \& Hughen, K. A. Synchroneity of tropical and high-latitude Atlantic temperatures over the last glacial termination. Science 301, 1361-1364 (2003).

56. Yu, S. \& Pritchard M. A. Strong role for the AMOC in partitioning global energy transport and shifting ITCZ position in response to latitudinally discrete solar forcing in CESM1.2. J. Climate, https://doi.org/10.1175/JCLI-D18-0360.1 (2019)

57. Cook, K. H. \& Vizy, E. K. Hydrodynamics of the Caribbean low-level jet and its relationship to precipitation. J. Clim. 23, 1477-1494 (2010).

58. Shen, C.-C. et al. Uranium and thorium isotopic and concentration measurements by magnetic sector inductively coupled plasma mass spectrometry. Chem. Geol. 185, 165-178 (2002).

59. Edwards, R. L., Gallup, C. D. \& Cheng, H. Uranium-series dating of marine and lacustrine carbonates. Rev. Mineral. Geochem. 52, 363-405 (2003).

60. Spötl, C. \& Vennemann, T. W. Continuous-flow IRMS analysis of carbonate minerals. Rapid Commun. Mass Spectrom. 17, 1004-1006 (2003).

61. Breitenbach, S. F. M. et al. Constructing proxy records from age models (COPRA). Climate 8, 1765-1779 (2012).

62. Pollock, A. L. et al. A mid-Holocene paleoprecipitation record from Belize. Palaeogeogr. Palaeoclimatol. Palaeoecol. 463, 103-111 (2016).

63. Daëron, M. et al. Most Earth-surface calcites precipitate out of isotopic equilibrium. Nat. Commun. 10, 429 (2019).

64. Lachniet, M. S. \& Patterson, W. P. Oxygen isotope values of precipitation and surface waters in northern Central America (Belize and Guatemala) are dominated by temperature and amount effects. Earth Planet. Sci. Lett. 284, 435-446 (2009).

65. Jungclaus, J. H., Lohmann, K. \& Zanchettin, D. Enhanced 20th-century heat transfer to the Arctic simulated in the context of climate variations over the last millennium. Climate 10, 2201-2213 (2014).

66. Stevens, B. et al. Atmospheric component of the MPI-M Earth System Model: ECHAM6. J. Adv. Model. Earth Syst. 5, 146-172 (2013).

67. Curtis, J. H. et al. A multi-proxy study of Holocene environmental change in the Maya Lowlands of Peten, Guatemala. J. Paleolimnol. 19, 139-159 (1998).

68. Hillesheim, M. B. et al. Climate change in lowland Central America during the late deglacial and early Holocene. J. Quat. Sci. 20, 363-376 (2005).
69. Lachniet, M. S., Bernal, J. P., Asmerom, Y., Polyak, V. \& Piperno, D. A 2400 yr Mesoamerican rainfall reconstruction links climate and cultural change. Geology 40, 259-262 (2012).

70. Lippold, J. et al. Does sedimentary ${ }^{231} \mathrm{~Pa} /{ }^{230} \mathrm{Th}$ from the Bermuda Rise monitor past Atlantic Meridional Overturning Circulation? Geophys. Res. Lett. 36, 12 (2009).

\section{Acknowledgements}

The authors gratefully acknowledge the support of the touristic Grutas del Rey Marcos, in San Juan Chamelco, Department of Alta Verapaz, Guatemala, to whom we are indebted for their collaboration. H.C. acknowledges grant NSFC 41888101. M.L. acknowledges NSF facilities grant EAR-0521196. A.W. thanks the University Ca Foscari of Venice for hosting him while much of the paper was written. Thanks to Thay-Ling Moya-Perez for milling the samples at UPRM, Jon Baker who loaded most of the samples in the mass spec at UNLV, and Jose Santiago for his help during the field trip to obtain the GU-RM1 sample. F.S.R.P. acknowledges funding from the Swedish Research Counci (FORAMS) as part of the Joint Programming Initiative on Climate and the Belmont Forum for the project "Palaeo-constraints on Monsoon Evolution and Dynamics (PACMEDY)" and the financial support from the Natural Sciences and Engineering Research Council of Canada (NSERC Grant RGPIN-2018-04981) and the Fonds de recherche du Québec-Nature et technologies (2020-NC-268559). The research was supported by National Science Foundation grant ATM 1003502.

\section{Author contributions}

A.W., D.Z. and M.L. conceived the project. M.L. did the isotopic analysis, and M.L. and R.V. did the age modeling. H.C. and R.L.E. provided the U/Th dates. D.Z., M.L., C.T. and F.S.R.P. did the statistical analysis. T.M. selected and retrieved the stalagmite and mapped its locations with respect to the surface. A.W., D.Z. and M.L. wrote most of the paper. A.W., D.Z., M.L., R.V., F.S.R.P., F.C.L., A.R. and S.R. contributed to discussion of results and to writing of the manuscript. T.M. selected and retrieved the stalagmite.

\section{Competing interests}

The authors declare no competing interests.

\section{Additional information}

Supplementary information is available for this paper at https://doi.org/10.1038/s41467 020-14490-y.

Correspondence and requests for materials should be addressed to A.W.

Peer review information Nature Communications thanks Sarah Metcalfe and the other, anonymous, reviewer(s) for their contribution to the peer review of this work.

Reprints and permission information is available at http://www.nature.com/reprints

Publisher's note Springer Nature remains neutral with regard to jurisdictional claims in published maps and institutional affiliations.

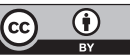

Open Access This article is licensed under a Creative Common Attribution 4.0 International License, which permits use, sharing, adaptation, distribution and reproduction in any medium or format, as long as you give appropriate credit to the original author(s) and the source, provide a link to the Creative Commons license, and indicate if changes were made. The images or other third party material in this article are included in the article's Creative Commons license, unless indicated otherwise in a credit line to the material. If material is not included in the article's Creative Commons license and your intended use is not permitted by statutory regulation or exceeds the permitted use, you will need to obtain permission directly from the copyright holder. To view a copy of this license, visit http://creativecommons.org/ licenses/by/4.0/.

(c) The Author(s) 2020 